\title{
3 \\ Pedogenic Processes in Thick Sand Deposits on a Marine Terrace, Central California
}

\author{
L. E. Moody and R. C. Graham \\ University of California \\ Riverside, California
}

\begin{abstract}
Pedological studies in thick sedimentary sequences are generally limited to the upper few meters. Field investigation of thick $(\leq 50 \mathrm{~m})$ sand deposits on an emergent Pleistocene marine terrace in central California showed morphological differences between the solum at the surface and the deep regolith. Based on morphological and geochemical features, four units were identified within the regolith. Two zones of active pedogenesis occur within three of these units. The surficial unit is in Holocene sand deposits (mixed, thermic, Argic Xeropsamments), and has darkened A horizons, a slightly reddened subsoil, and incipient lamellae at the depth of wetting front infiltration. These lamellae have slightly more clay and Fe oxides than the soil above. Mineral weathering is intense at the surface. The other zone of active pedogenesis is at the base of the regolith, where a lithologic discontinuity above the terrace platform forms an aquitard, and throughflow occurs. Meteoric water percolates through thin regolith deposits above the shoreline angle, and at other locations on the terrace where sediment has been removed by erosion. Percolating water carries clay, organie matter, and solutes to the water table. Weathering is intense within this basal unit. Illuviation of clays and $\mathrm{Fe}$ oxides, and precipitation of Fe oxides and silica occur within this unit. As pore space is filled, fractures and channels become paths for saturated water flow. Eluviation of Fe occurs at these sites. Most of the intervening regolith is isolated from current pedogenesis by its great depth and a relatively dry Holocene climate. Well-developed lamellae are preserved as relicts of Pleistocene episodes of soil formation. These lamellae formed by illuviation of clay and Fe oxides, and were sites of silica precipitation. The conceptual model presented here is intended to facilitate understanding of pedogenic and geomorphological evolution of marine terrace deposits, and to assist with the interpretation of groundwater flow in these terrace systems.
\end{abstract}

Pedological studies in thick sedimentary sequences are usually limited to the upper few meters. These depths generally encompass the solum and parent material. Some soil studies have recognized deep occurrence of pedogenic

Copyright $\odot 1994$ Soil Science Society of America, $677 \mathrm{~S}$. Segoe Rd., Madison, WI 53711 , USA. Whole Regolith Pedology. SSSA Special Publication no. 34. 
processes. Jenny (1980) noted reticulate mottling "at great depth" on Pleistocene marine terraces in northern California. Other examples of deep pedogenesis include weathering at depths greater than $5 \mathrm{~m}$ on marine terraces in Oregon (Bockheim et al., 1992), and silica cementation to deeper than 4.5 $m$ in late Quaternary sands on marine terraces in New Zealand (Ross et al., 1989).

Field investigations of thick sand deposits on an emergent Pleistocene marine terrace south of Los Osos, California, showed morphological differences between the surface and the deep regolith. The solum at the surface contains darkened A horizons, reddened subsoil, and thin discontinuous lamellae. Below this, the deep regolith contains lamellae in the upper part and mottles in the basal part. The objectives of this study were to describe morphological and chemical features in the solum and deep regolith, and to interpret these features with respect to the probable processes that caused them.

\section{MATERIAL AND METHODS}

\section{Description of Study Area}

The study was conducted in a thick $(\leq 50 \mathrm{~m})$ sand deposit on a Pleistocene wavecut terrace, south of Los Osos, California (Fig, 3-1, inset). The elevation of the terrace platform is $1.5 \mathrm{~m}$ at the beach front (Fig. 3-1). The shoreline angle is buried, but is probably at a higher elevation, as wavecut platforms generally slope gently seaward (Kern, 1977). The topographic surface is at 10 - to $50-\mathrm{m}$ elevation. A terrace at Cayucos, $15 \mathrm{~km}$ to the north and at approximately the same elevation as the terrace in this study, was dated at between 113000 and 125000 years before the present (YBP) by $U$-series dating of corals within the sediments (Stein et al., 1991). Midden material on coastal bluffs in the study area has been dated at about 5000 YBP (Montana de Oro State Park staff, 1991, personal communication). Major sand deposition is, therefore, late Pleistocene to early Holocene (Orme \& Tchakerian, 1986). Sand is transported from the north by littoral drift. From petrographic analyses, modern beach and dune sands are shown to consist of about $40 \%$ quart $z, 20 \%$ feldspars, $15 \%$ chert fragments, $10 \%$ siliceous shale fragments, which are mainly opal, $15 \%$ Fe-silicates including amphiboles, pyroxenes, serpentine, and chlorite, and $<2 \%$ accessory minerals, including micas, magnetite, chromite, garnet, and calcium carbonate. Winds are dominantly from the northwest (Orme \& Tchakerian, 1986). Average annual precipitation is $460 \mathrm{~mm} \mathrm{yr}^{-1}$, most of which occurs November through April. Average annual temperature is $15^{\circ} \mathrm{C}$ (Ernstrom, 1984).

\section{Field Description and Sampling}

Investigations of auger borings and exposures in recent gullies and blowouts were used to determine the location for a typical pedon, which was 


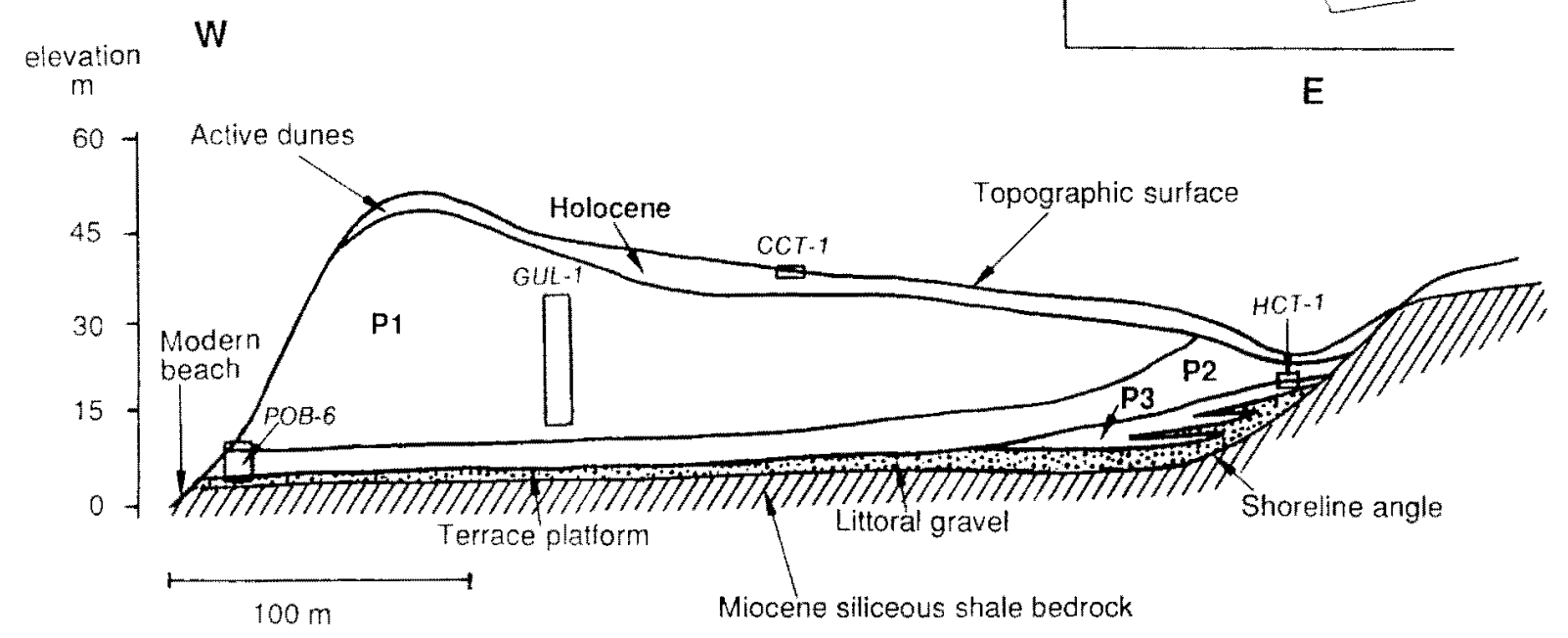

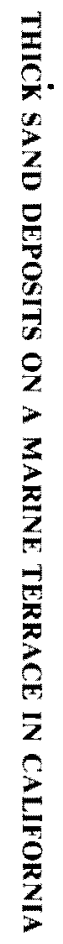

Fig. 3-1. Cross-section of Pleistocene terrace, Los Osos, California, showing terrace morphology, stratigraphic units, and locations of pedons and stratigraphic sections (inset shows location of study site). 
described and sampled in a hand-excavated pit according to standard methods (Soil Survey Staff, 1975, 1984). Deep regolith was described and sampled from exposures within recent gullies and wave-cut bluffs using standard stratigraphic descriptive techniques (Blatt et al., 1980), supplemented by soil descriptive methods, after excavating into exposure walls 0.25 to $1 \mathrm{~m}$. Terrace morphology terminology follows Kern (1977). Units identified within the regolith were separated on the basis of morphological and geochemical features.

\section{Laboratory Analyses}

Particle-size analysis followed removal of organic matter by $\mathrm{H}_{2} \mathrm{O}_{2}$ digestion, chemical dispersion using 10\% $\mathrm{Na}$ hexametaphosphate, and physical dispersion by mixing for $5 \mathrm{~min}$ in a blender. Sand, silt, and clay were determined by sieving and pipette (Gee \& Bauder, 1986). Selective dissolution techniques used to determine $\mathrm{Fe}$ and $\mathrm{Si}$ in the whole soil were sodium pyrophosphate $\left(\mathrm{Fe}_{\mathrm{p}}\right)$ (modified from Bascomb, 1968), acid ammonium oxalate in the dark $\left(\mathrm{Fe}_{\mathrm{o}}\right.$ and $\left.\mathrm{Si}_{\mathrm{o}}\right)$ (Jackson et al., 1986), sodium citratebicarbonate-dithionite ( $\left.\mathrm{Fe}_{\mathrm{d}}\right)$ (Jackson et al., 1986), and Tiron ( $\mathrm{Si}_{\mathrm{f}}$ ) (Kodama \& Ross, 1991). Iron and Si were determined by atomic absorption spectrophotometry and were calculated on a dry weight basis. Most samples were extracted and analyzed in duplicate. Soil $\mathrm{pH}$ was determined in a 1:1 soil/water paste (McLean, 1982). Micromorphology of selected pedogenic features was described using polarized light microscopy. Descriptive terminology follows Brewer (1976). Mineralogy of the fine sand fraction was determined by polarized light microscopy, and quantified by grain counts of 300 to 600 grains per sample (Brewer, 1976). Ratios of weathered to total (weathered + fresh) feldspar grains were calculated as a weathering index.

\section{RESULTS AND DISCUSSION}

\section{Terrace Morphology and Stratigraphy}

The terrace platform is cut into Miocene siliceous shale bedrock (Fig. $3-1)$. The shoreline angle is buried, but the bedrock riser to the next terrace has been partially exhumed. The platform is overlain by 1.5 to $9 \mathrm{~m}$ of Pleistocene littoral gravels. Up to $40 \mathrm{~m}$ of Pleistocene beach and dune sands (Units P1, P2, and P3; Fig. 3-1) overlie the gravels. Sands are thinly interbedded with gravels above the shoreline angle. Holocene eolian sands, 1.5 to $7 \mathrm{~m}$ thick, overlie the Pleistocene sand deposits. The sand deposits pinch out south of the study area, becoming replaced by a thickening sequence of alluvial and littoral gravels. The bedrock platform dips to the north with a $0.8 \%$ slope. The Holocene deposit makes up one unit. The Pleistocene deposit is divided into three units; P1, P2, and P3 (Fig. 3-1). 


\section{Description of Units}

\section{Holocene Unit}

The sand of the Holocene unit is still being reworked and redistributed by wind at the top of the coastal bluffs (Fig. 3-1). Most of the surface is stabilized by shrubs, dominantly Morro manzanita (Arctostaphylos morroensis Wies. and Schreib.) and buck brush (Ceanothus cuneatus Nutt.), and annual grasses. Within the typical pedon (CCT-1, Fig. 3-1), clay content and chroma increase slightly with depth to $1 \mathrm{~m}$, but with no discernible evidence of illuviation until the development of thin, wavy, discontinuous lamellae below $1.3 \mathrm{~m}$ (Table $3-1$ ). The $\mathrm{Fe}_{\mathrm{p}}$ and $\mathrm{Fe}_{\mathrm{o}}$ increase to a maximum at $1 \mathrm{~m}$, then decrease (Table $3-2$ ). The $\mathrm{Fe}_{\mathrm{p}}$ represents soil Fe complexed with organic matter (Bascomb, 1968). Darkened soil colors (Table 3-1) indicate that most of the organic matter is retained in the soil above $1 \mathrm{~m}$, where the rate of organic matter accumulation exceeds its decomposition. Ferrihydrite (approximated by $\mathrm{Fe}_{0}-\mathrm{Fe}_{p}$; Bascomb, 1968) and crystalline Fe oxides (approximated by $\mathrm{Fe}_{\mathrm{d}}-\mathrm{Fe}_{\mathrm{o}}$; Bascomb, 1968) are present in the solum, but neither shows a significant trend with depth (Fig. 3-2). Allophanic and adsorbed silica ( $\mathrm{Si}_{0}$; Kodama \& Ross, 1991) is insignificant in this profile (Fig. 3-3). Opaline silica probably reflects dissolution of opaline silica shale fragments in the sand fraction during the extraction process (Fig. 3-3). Ratios of weathered to total feldspar suggest that weathering intensity is high at the surface and decreases with depth (Fig. 3-4). Silica released by weathering of feldspars has been leached out the profile. The soil is acidic, with $\mathrm{pH}$ values $<6$ throughout (Table 3-2).

Incipient lamellae containing slightly more clay (Table $3-1$ ) and Fe than the matrix (Fig. 3-2) begin at $1.3 \mathrm{~m}$. We calculated the depth of infiltration of a wetting front resulting from a high intensity rain event $(60 \mathrm{~mm})$, which occurred within a 24 -h period in January 1983, an El Niño year (NOAA, 1983). Assuming no evapotranspiration and no runoff, in an initially dry fine sand with a water-holding capacity of $0.05 \mathrm{~cm} \mathrm{~cm}^{-1}$ (Baywood fine sand; Ernstrom, 1984), the wetting front would infiltrate to a depth of 1.2 $\mathrm{m}$, which is very close to the depth of lamellae occurrence in this soil. Laboratory simulations have shown that lamella formation begins where a wetting front stops its downward infiltration, and clays are deposited by settling or drying (Dijkerman et al., 1967). Therefore, we conclude that the incipient lamellae in this profile are Holocene illuvial features.

\section{Pleistocene Unit P1}

The Pleistocene unit P1, underlying Holocene sands, contains well developed clay and Fe-oxide-enriched lamellae at 20 - to $40-\mathrm{m}$ depth. The typical section (GUL-1, Fig. 3-1) begins at 7-m depth, and consists of $2 \mathrm{~m}$ of buried $\mathrm{A}$ horizon (7-9 $\mathrm{m}$ depth, Table 3-1), overlying $12 \mathrm{~m}$ of homogeneous fine sand (9- to $21 \mathrm{~m}$ depth, Table $3-1$ ), which overlies $3 \mathrm{~m}$ of thinly bedded 
Table 3-1. Morphological properties of soil and regolith, pedon CCT-1 and stratigraphic sections GUL-1, POB-6, and HCT-1.

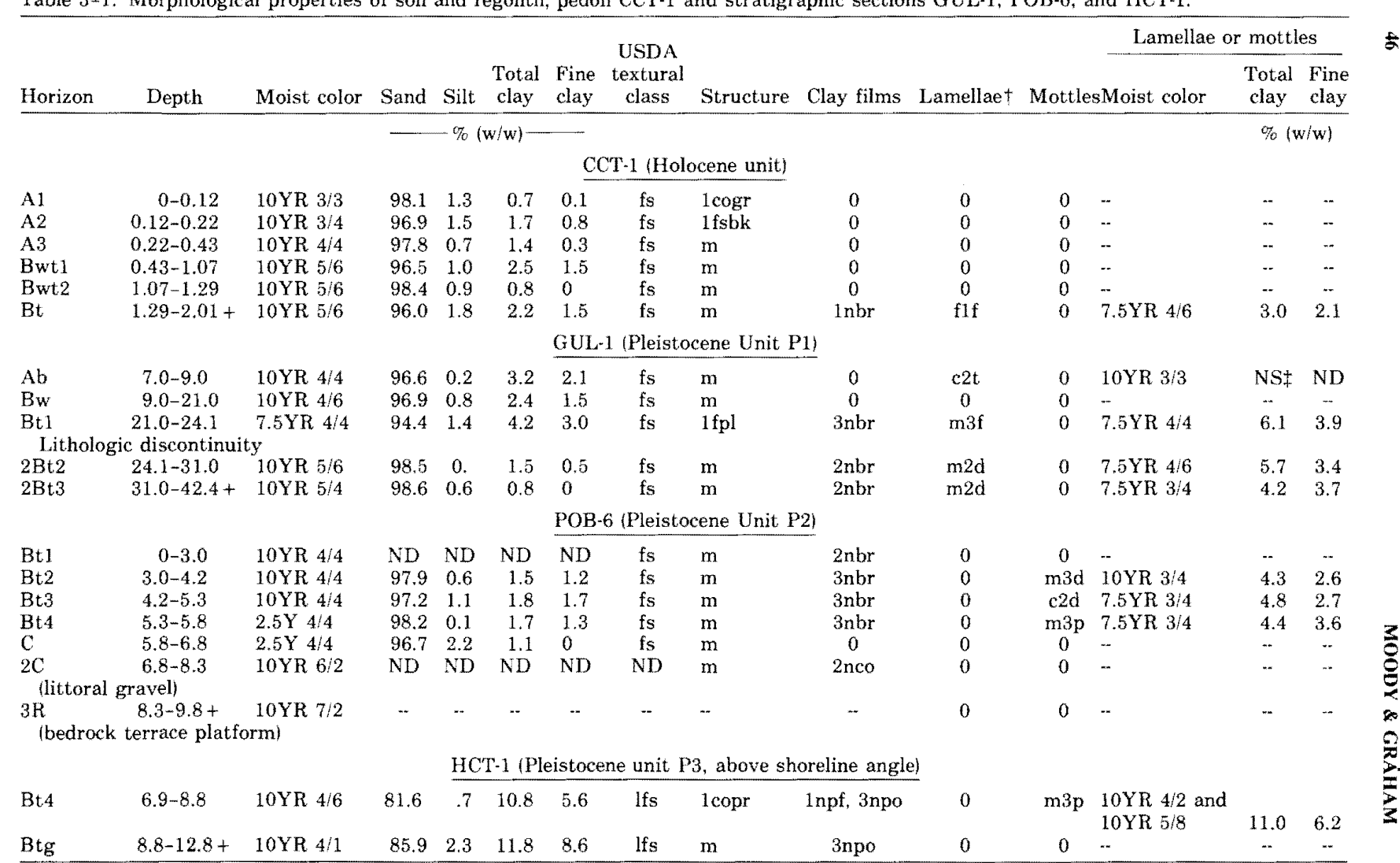

+ Notation used to describe lamellae follows notation to describe mottles (Soil Survey Staff, 1975 ).

$\$ \mathrm{ND}=$ not determined. 
Table 3-2. Selected chemical features of soil and regolith, pedon CCT-1 and stratigraphic sections GUL-1, POB-6, and HCT-1.

\begin{tabular}{|c|c|c|c|c|c|c|c|c|}
\hline & Depth & $\mathrm{Fe}_{\mathrm{p}}$ & $\mathrm{Fe}_{0}$ & $\mathrm{Fe}_{\mathrm{d}}$ & $\mathrm{Fe}_{\mathrm{o}} / \mathrm{Fe}_{\mathrm{d}}$ & $\mathrm{SI}_{o}$ & $\mathrm{Si}_{\mathrm{t}}$ & $\mathrm{pH}$ \\
\hline & $\mathrm{m}$ & & $\mathrm{g} \mathrm{kg}^{-1}$ & - & & \multicolumn{2}{|c|}{$-\mathrm{g} \mathrm{kg}^{-1}-$} & \\
\hline \multicolumn{9}{|c|}{ CCT-1 } \\
\hline & 0.12 & 0.30 & 0.61 & 2.71 & 0.22 & 0.02 & 1.50 & 5.50 \\
\hline & 0.22 & 0.45 & 0.68 & 2.54 & 0.27 & 0.02 & 1.43 & 5.85 \\
\hline & 0.43 & 0.36 & 0.75 & 2.38 & 0.32 & 0.02 & 1.46 & 5.74 \\
\hline & 1.07 & 0.51 & 0.83 & 2.55 & 0.32 & 0.08 & 1.28 & 5.52 \\
\hline & 1.29 & 0.16 & 0.44 & 2.70 & 0.16 & 0.04 & 0.39 & 5.73 \\
\hline Matrix & 2.01 & 0.21 & 0.50 & 2.62 & 0.19 & 0.04 & 1.23 & 5.62 \\
\hline Lamellae & 2.01 & 0.28 & 0.65 & 2.92 & 0.22 & 0.05 & 1.25 & 5.86 \\
\hline \multicolumn{9}{|c|}{ GUL-1 } \\
\hline Matrix & 24.1 & 0.08 & 0.68 & 2.31 & 0.29 & 0.09 & 3.59 & 5.90 \\
\hline Lamellae & 24.1 & 0.08 & 0.96 & 3.29 & 0.22 & 0.11 & 6.06 & 5.86 \\
\hline Matrix & 31.0 & 0.04 & 0.45 & 1.73 & 0.26 & 0.03 & 1.12 & 6.56 \\
\hline Lamellae & 31.0 & 0.07 & 0.45 & 2.23 & 0.20 & 0.14 & 3.83 & 5.58 \\
\hline Matrix & 42.4 & 0.06 & 0.29 & 2.04 & 0.14 & 0.03 & 1.20 & 6.32 \\
\hline Lamellae & 42.4 & 0.07 & 0.50 & 1.76 & 0.28 & 0.07 & 3.45 & 6.61 \\
\hline \multicolumn{9}{|c|}{ POB-6 } \\
\hline Matrix & 4.20 & 0.17 & 0.70 & 1.40 & 0.50 & 0.04 & 1.14 & 7.36 \\
\hline Mottle & 4.20 & 0.21 & 1.03 & 3.80 & 0.27 & 0.14 & 6.38 & 7.54 \\
\hline Matrix & 5.30 & 0.07 & 0.59 & 3.14 & 0.19 & 0.08 & 1.95 & 7.75 \\
\hline Mottle & 5.30 & 0.72 & 1.46 & 4.74 & 0.31 & 0.66 & 5.78 & 7.28 \\
\hline Matrix & 5.80 & 0.15 & 0.83 & 1.19 & 0.70 & 0.10 & 1.21 & 7.64 \\
\hline Mottle & 5.80 & 0.76 & 1.07 & 8.27 & 0.13 & 0.42 & 6.54 & 7.31 \\
\hline Matrix & 6.80 & 0.25 & 0.75 & 2.01 & 0.37 & 0.07 & 2.12 & 7.75 \\
\hline \multicolumn{9}{|c|}{ HCT-1 } \\
\hline Matrix & 8.80 & 0.13 & 0.17 & 13.07 & 0.09 & 0.11 & 2.37 & 5.47 \\
\hline Mottle & 8.80 & 0.08 & 0.16 & 2.02 & 0.08 & 0.06 & 10.42 & 5.28 \\
\hline
\end{tabular}

fine sand, in which planar, horizontal lamellae have coalesced (21- to 24-m depth, Table $3-1$ ). This layer unconformably overlies $7 \mathrm{~m}$ of fine sand with mostly planar, nearly horizontal lamellae, 0.5 to $3 \mathrm{~cm}$ thick and 0.6 to $6 \mathrm{~cm}$ apart (24- to 31-m depth, Table 3-1). This layer overlies $11 \mathrm{~m}$ of cross-bedded, interbedded fine and medium sand, with lamellae that are fainter than above, 0.1 to $1 \mathrm{~cm}$ thick, 0.5 to $1 \mathrm{~cm}$ apart, and follow cross bedding (31- to $42-\mathrm{m}$ depth, Table 3-1). The thickness of the Ab horizon (7-9 m, Table 3-1) suggests a cumulic soil-depositional system, consistent with observations in modern dunes, where vegetation colonizing active dunes traps sand, and adds organic matter which darkens the sand. We have observed buried, darkened horizons $>1 \mathrm{~m}$ thick at several locations along the coastal bluffs. Morphological and mineralogical data are not conclusive for determining if the buried A horizon and underlying homogeneous sand have a genetic relationship with the zone containing lamellae (21- to $42-\mathrm{m}$ depth), or if they are a younger deposit.

All lamellae contain more total and fine clay than the matrix (Table 3-1). Lamellae have abundant free grain ferriargillans, coating and bridging sand grains, with strong continuous orientation. Most grain coatings are approximately equal in thickness on the upper and lower sides of sand grains, but 

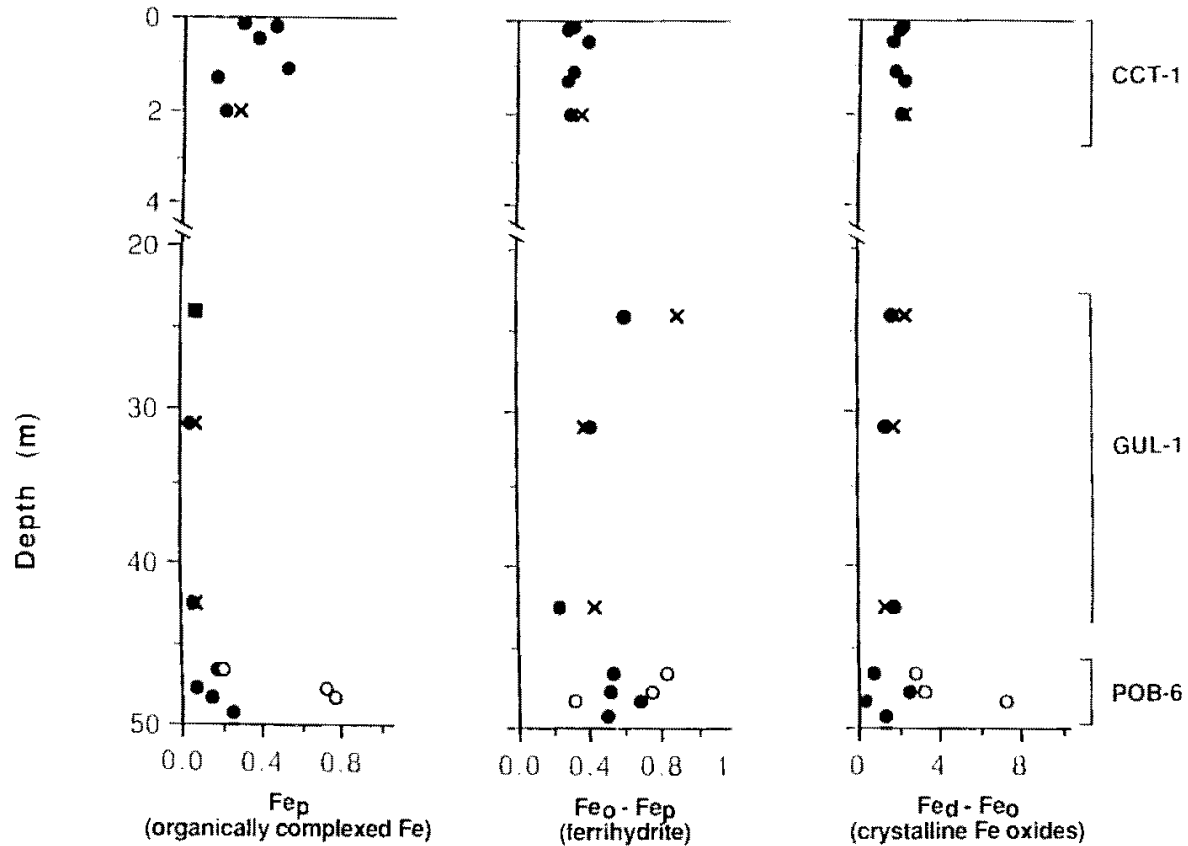

- Marrix

$\times$ Lamellae

o High chroma moties 


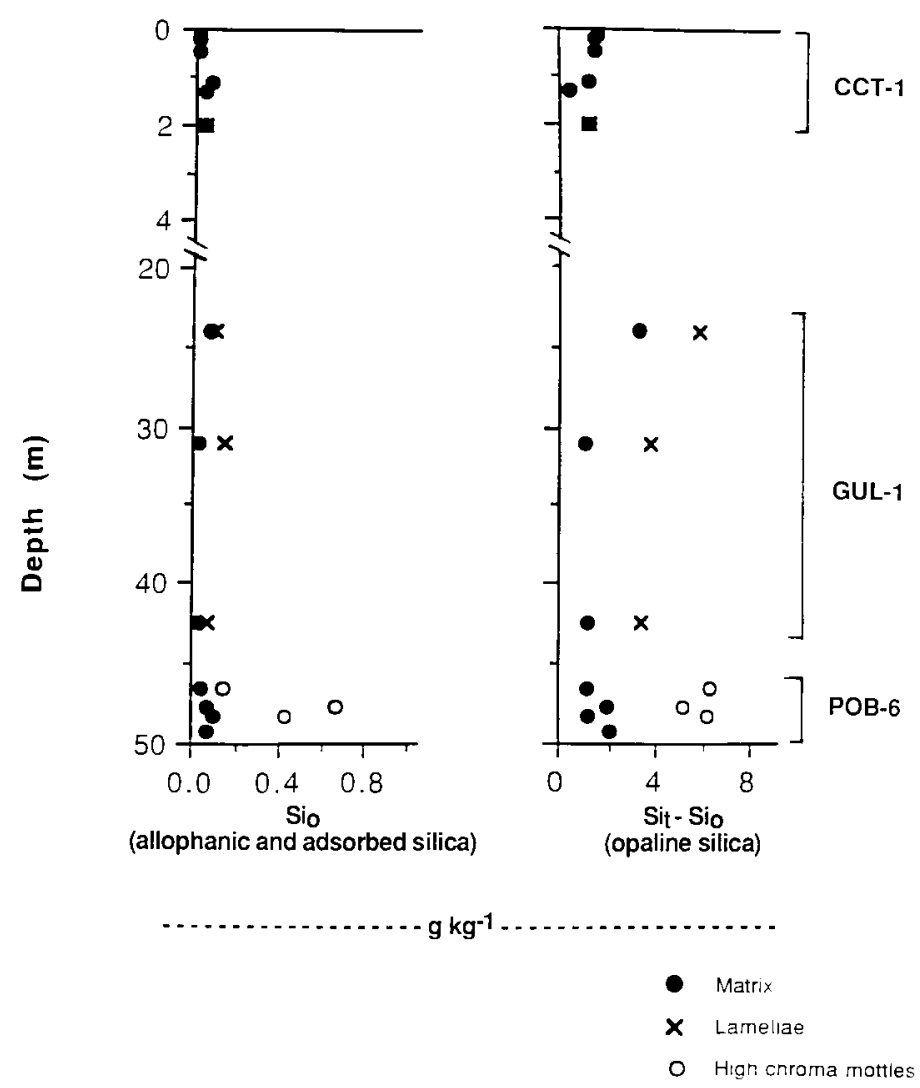

Fig. 3-3. Variation of pedogenic Si with depth, for Holocene unit and Pleistocene Units Pl and P2. Note change in vertical scale between 4- and 20-m depth.

rarely, coatings are thicker on the upper sides of some grains. Strongly oriented argillans within lamellae are common and are considered definite evidence for illuvial origin of the lamellae (Dijkerman et al., 1967; Torrent et al., 1980). Thicker argillans on the tops of grains are considered evidence for gravity settling of clays (Dijkerman et al., 1967). Argillans in lamellae observed in this study are similar to these produced by illuviation experiments (Dijkerman et al., 1967), supporting an illuvial origin for lamellae.

Lamellae are redder than the interlamellae matrix (Table $3-1$ ), and contain more $\mathrm{Fe}_{\mathrm{o}}$ and $\mathrm{Fe}_{\mathrm{d}}$ than the matrix (Table 3-2). Lamellae contain more ferrihydrite, but no more crystalline Fe oxides, than the Holocene solum (Fig. 3-2), and $\mathrm{Fe}_{\mathrm{o}} / \mathrm{Fe}_{\mathrm{d}}$ ratios are similar to those in the Holocene solum (Table 3-2), suggesting similar Fe oxide crystallinity. In well-drained soils, $\mathrm{Fe}$ oxide crystallinity generally increases with soil age (Aniku \& Singer, 1990). That Fe oxides are not more crystalline in Unit P1 than in the Holocene soil sug- 
Fig. 3-4. Variation in ratios of weathered total (weathered + fresh) feldspars with depth, for Holocene unit and Pleistocene Units P1 and $P 2$. Note change in vertical scale between 4 - and $20 \mathrm{~m}$ depth.

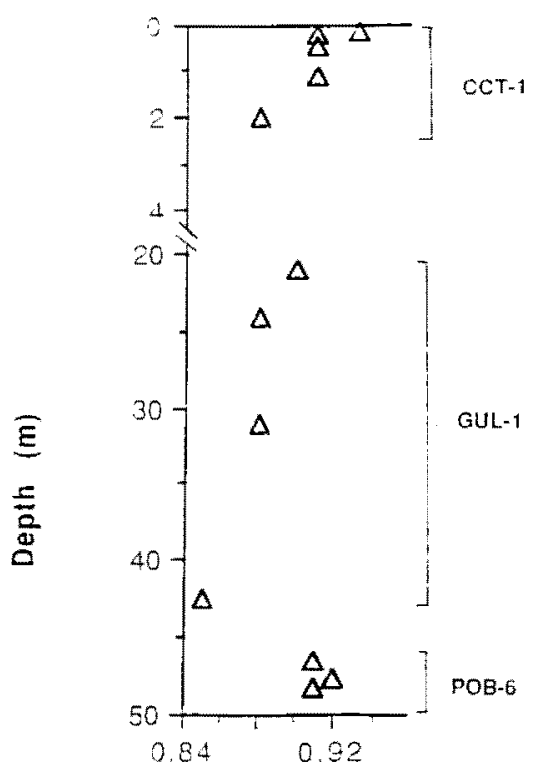

gests some mechanism is inhibiting transformation of ferrihydrite to goethite or hematite. Lamellae in P1 contain slightly more $\mathrm{Si}_{0}$ than the Holocene soil, and substantially more opaline silica (Fig. 3-3). Opaline silica content of lamellae decreases with depth but is always higher than in the matrix and in the Holocene solum (Fig. 3-3). Silica adsorption onto ferrihydrite surfaces has been shown to inhibit transformation of ferrihydrite to crystalline Fe oxides (Carlson \& Schwertmann, 1981). Precipitation and polymerization of adsorbed Si-O groups on Fe oxide particle surfaces has been suggested as a mechanism for formation of pedogenic opaline silica (Chadwick et al., 1987).

The depth of lamellae, the thickness of the unit, and especially the presence of at least one unconformity, suggests that Unit P1 represents a series of depositional events with intervening periods of soil formation throughout the late Pleistocene. Weathering intensity, estimated by feldspar weathering ratios, is lower than the Holocene solum, and decreases with depth (Fig. 3-4). Because of its depth, and a relatively dry Holocene climate, this unit is now protected from most pedogenic processes. The lamellae are relicts of episodes of soil formation during the Pleistocene.

\section{Pleistocene Unit P2}

Pleistocene Unit P2 is represented by section POB-6 (Fig. 3-1, Table 3-1). This unit directly overlies the gravel strata at the modern coastal bluffs, and overlies Unit P3 above the shoreline angle (Fig. 3-1). It consists of a dark yellowish brown (10YR 4/4) to olive brown $(2.5 \mathrm{Y} 4 / 4)$ matrix containing faint to distinct, dark yellowish brown (IOYR 3/4) to dark brown (7.5YR $3 / 4)$ mottles as rounded blocks and bands 2 to $30 \mathrm{~cm}$ in diameter. The matrix 
resembles unweathered sand in color and texture. Mottles contain more clay and more fine clay than the matrix (Table 3-1). Mottles have a dry consistence that is slightly hard, harder than the matrix, indicating cementation.

Most ferriargillans within the mottles are free grain and channel ferriargillans with strong continuous orientation, are distinctly redder, and are either aggregates with rounded outlines, probably $\mathrm{Fe}$ oxide pseudomorphs, or are disaggregated and nearly fill pore throats of packing voids. Flecked and strongly oriented ferriargillans are often interlayered. These two kinds of ferriargillans suggest two modes of clay and $\mathrm{Fe}$ oxide deposition. The flecked ferriargillans resemble authigenic Fe oxides (Scholle, 1979), produced by weathering of Fe-bearing sand grains, and subsequently dispersed and transported into packing voids. Laboratory experiments with lateral flow of clay suspensions through sand have shown that argillans with strong continuous orientation coat and bridge sand grains and fill pore throats (Dijkerman et al. 1967). The experimentally produced free grain argillans and bridges between grains showed no preferential thickness related to direction of flow, but tended to be concentrated in pore throats (Dijkerman et al., 1967). In Unit P2 of our study, oriented argillans in mottles have similar distribution and morphology, suggesting they formed by illuviation.

Mottles contain more of all forms of extractable Fe and Si than the matrix (Table 3-2). They contain more extractable $\mathrm{Fe}$, especially $\mathrm{Fe}_{\mathrm{p}}$, and Si than any part of Unit P1 (Fig. 3-2 and 3-3). These results suggest that mottles are sites where illuvial $\mathrm{Fe}$ oxides, Fe-organic matter chelates, and clays are deposited, and where Fe oxides and silica have precipitated. The $\mathrm{pH}$ values are $\approx 7$, substantially higher than in any other part of the regolith (Table 3-2). Weathered total feldspar ratios are as high in this unit as those in the surface soil, suggesting relatively intense weathering in Unit P2 (Fig. 3-4).

Lateral flow from Unit P2 has been observed in the field. During the rainy season, ephemeral springs exfiltrate from the sand-gravel contact at irregular intervals along the coastal bluff. A water sample extracted from one of these seeps had a pH of 6.98 and the following concentrations ( $\mathrm{mg}$ $\mathrm{L}^{-1}$ ) of elements: $\mathrm{Si}, 14.5 ; \mathrm{Ca}, 17.1 ; \mathrm{Mg}, 20.1 ; \mathrm{Na}, 88.4 ; \mathrm{Al}, 0.44$; and $\mathrm{Fe}$, 0.32 . Dissolved organic $C\left(9.4 \mathrm{mg} \mathrm{L}^{-1}\right)$ is likely from organic acids that chelate metal ions in solution. The organic matter and solutes have been leached through thin regolith and transported in throughflow. Some solutes may be contributed by mineral weathering within the basal unit.

\section{Pleistocene Unit P3}

Pleistocene Unit P3 is found only above the shoreline angle, and consists of sands thinly interbedded with gravels (Fig. 3-1). Section HCT-1 represents Unit P3 (Fig. 3-1, Table 3-1). The upper part of this unit consists of a dark yellowish brown matrix (10YR 4/6) with distinct to prominent dark grayish brown (10YR 4/2) mottles. The mottles appear to be eluvial features adjacent to vertical fractures and root channels. A yellowish brown (10YR $5 / 8$ ) band is adjacent to the boundary of some, but not all, of the mottles. 
Within the matrix, ferriargillans with strong continuous orientation are interlayered with flecked ferriargillans. Both types coat grains and bridge between grains, as in Unit P2, and strongly oriented ferriargillans fill channels. As in Unit $\mathrm{P} 2$, we conclude that the ferriargillans are of both illuvial and authigenic origins. Flecked material is not found in the low chroma mottles, and the high chroma matrix contains more extractable Fe than the mottles (Table 3-2), suggesting that they formed by dissolution of $\mathrm{Fe}$ oxides under saturated conditions, and eluviation of Fe via preferential flow paths (Veneman et al., 1976; Vepraskas \& Wilding, 1983). Below the mottled layer, sandy sediments decrease in chroma and value until they are almost completely and uniformly dark gray (10YR 4/1) (8.8- to 12.8-m depth, Table 3-1).

The clay content of the high and low chroma material of Unit P3 is greater than in any of the materials of the overlying units (Table 3-1). The matrix contains more crystalline Fe oxides than all overlying units, suggesting greater Fe oxide crystallinity (Table $3-1$ ). The $\mathrm{pH}$ values are $<6$ (Table $3-2$ ). The ratio of weathered to total feldspar is 0.92 , indicating weathering intensity of the same magnitude as in Unit P2 and the Holocene surface soil.

\section{Interpretation of Processes}

Morphological, chemical, and mineralogical differences between the Holocene solum and the deep regolith suggest different processes (Fig. 3-5). Vegetation stabilizing the Holocene deposit contributes to organic matter accumulation in the surface soil, resulting in darkening of A horizons, Weathering, especially of feldspars and Fe silicates, has occurred. Ferrihydrite and crystalline $\mathrm{Fe}$ oxides have formed, but much of the Fe released by weathering has entered into complexes with organic matter. Most clay and Fe oxides are evenly distributed in the profile, but some illuvial deposition is apparent in incipient lamellae, indicating that dominant water movement is downward (Fig. 3-5).

The thickest (typically 20 to $40 \mathrm{~m}$ ) part of the regolith is characterized by lamellae, which are relict features suggestive of episodes of pedogenesis that occurred during the Pleistocene. These lamellae were formed by vertical illuviation of clay and Fe oxides in a well-drained environment dominated by downward water movement (Fig. 3-5). Silica has precipitated in lamellae, and inhibits transformation of ferrihydrite to crystalline Fe oxides. This unit is currently unaffected by pedogenesis because it is below the depth of downward leaching under the present climate, and is above the zone of throughflow (Fig. 3-5).

Marine terrace morphology and the stratigraphic sequence of sediments deposited on the terrace directly affect the flow of water through basal sands (Fig. 3-5). The gravel overlying the bedrock plat form is an aquitard, producing a perched water table and throughflow within basal sands (Fig. 3-5). Meteoric water reaches the water table through thin regolith deposits above the shoreline angle, or elsewhere on the terrace where sediment has been removed by erosion. As water moves through sandy sediments, it carries clays, Fe oxides, organic matter, and dissolved $\mathrm{Si}, \mathrm{Fe}$, and other ions. Weathering 


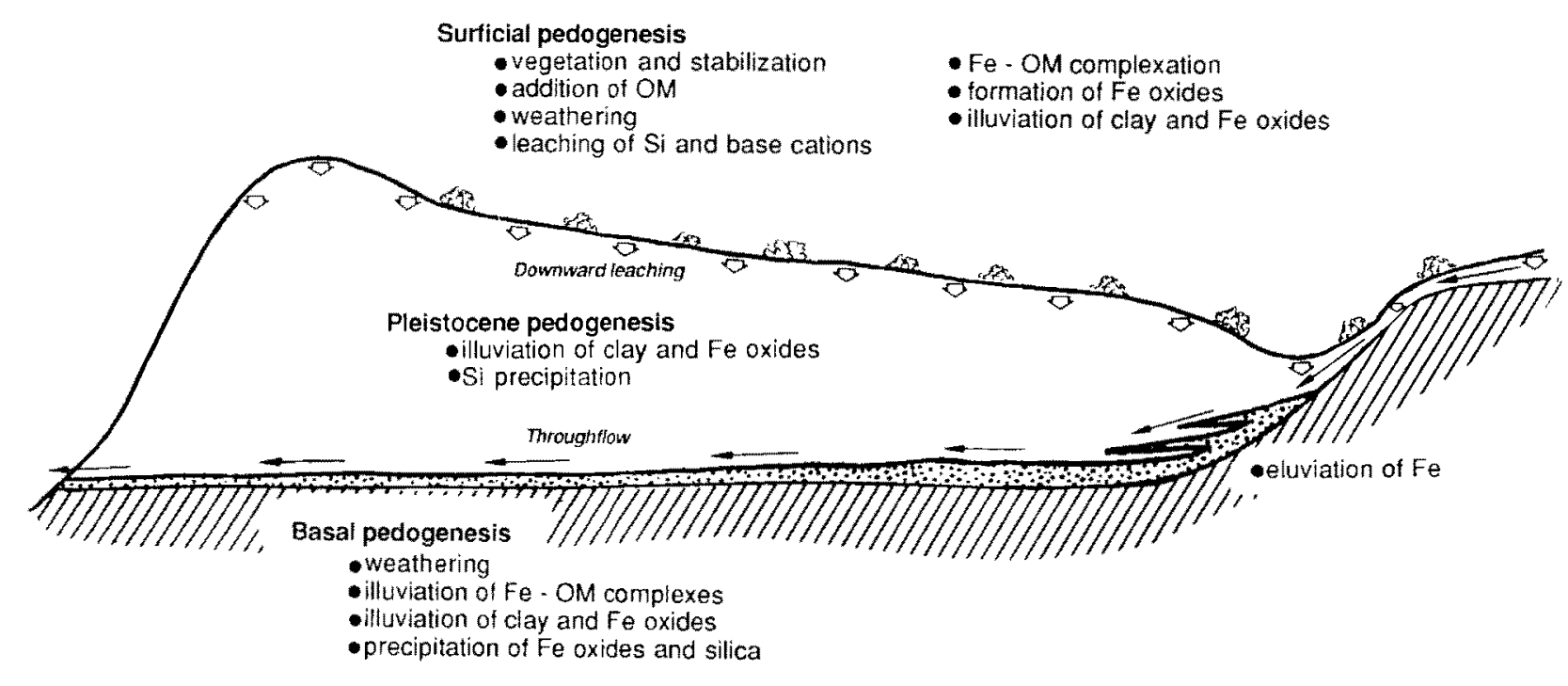

Fig. 3-5. Summary of processes in surface soil and deep regolith. Arrows show dominant direction of water movement. 
occurs within the basal sands, adding more $\mathrm{Si}$ and $\mathrm{Fe}$ to the throughflow. Clays, $\mathrm{Fe}$ oxides, organic matter, and dissolved $\mathrm{Fe}$ and $\mathrm{Si}$ are transported in lateral illuviation above the bedrock substratum of the shoreline angle (Fig. 3-5). Dissolved $\mathrm{Fe}$ and $\mathrm{Si}$ precipitate. As clays, Fe oxides, and silica plug packing voids, water that could formly flow through the sand as a relatively uniform wetting front is now concentrated into channels and fractures, which must assume larger roles as paths for saturated water flow. Iron oxides are dissolved, and as water is drawn into adjacent sediment by capillary attraction, some Fe oxides precipitate in a yellowish brown band adjacent to the gleyed site. Some $\mathrm{Fe}$, as well as other ions, are carried in throughflow to an exfiltration site (Fig. 3-5).

Although the deposition of Fe oxides, clays, and silica from seasonal groundwater in the Pleistocene basal Unit $\mathrm{P} 2$ could be regarded as geological, the processes may be considered pedogenic in that they appear to be the same as those that operate in soils. For example, illuviation is regarded as a pedogenic process (Buol et al., 1980; Bates \& Jackson, 1984; Birkeland, 1984). Therefore, we consider the processes, weathering and illuviation, occurring in the basal unit, to be pedogenic processes even though the basal unit is not a soil. This question of terminology underscores the need for more study of the deep regolith by soil scientists.

\section{CONCLUSIONS}

There are two distinct zones of active pedogenic processes. One is at the surface where the regolith meets the atmosphere and biosphere. The other is at the base of the regolith, where a lithologic discontinuity forms an aquitard, and throughflow occurs. Much of the regolith is isolated from current pedogenic processes, though features of previous pedogenic episodes are preserved.

Current surficial and deep pedogenic processes have important implications for interpretation of soil genesis and geomorphology. Morphological features associated with throughflow conditions in the youngest emergent terrace, described in this study, occur near the surface on older terraces. These features are now understood to have been produced by basal pedogenesis and subsequently exhumed, rather than having been the result of a long period of surficial pedogenesis. Morphological features associated with basal throughflow and pedogenesis also help locate relict shoreline angles on old, highly dissected, uplifted terraces. Understanding water flow through the regolith helps explain silica cementation within terrace sediments, which in turn influences erosion and landforms associated with terrace dissection.

Marine terraces often are used for agriculture and residential development. The conceptual model of surficial and deep pedogenesis presented here has implications for modern environmental problems. For example, pollutants may most readily gain entry to groundwater through thin regolith deposits above the shoreline angle, and subsequently can be widely dispersed by throughflow, 


\section{REFERENCES}

Aniku, J.R.F., and M,J. Singer. 1990. P-edogenic iron oxide trends in a marine terrace chronosequence.Soil Sci. Soc. Am. J. 54:147-152.

Bascomb, C.L. 1968. Distribution of pyrophosphate-extractable iron and organic carbon in soils of various groups. 3 . Soil Sci. 19:251-268.

Bates, R.L., and J.A. Jackson (ed.). 1984. Dictionary of geological terms. 3rd ed. Doubleday, New York.

Birkeland, P.W. 1984. Soils and geomorphology. Oxford Univ. Press, New York.

Blatt, H., G. Middleton, and R. Murray. 1980. Origin of sedimentary rock5. 2nd ed. PrenticeHall, Englewood Cliffs, NJ.

Bockheim, J.G., H.M. Kelsey, and J.G. Marshall. 1992. Soil development, relative dating, and correlation of late Quaternary marine terraces in southwestern Oregon. Quat. Res, 37:60-74.

Brewer, R. 1976. Fabric and mineral analysis of soils. 2nd ed. Robert E. Krieger Publ. Co., Huntington, NY.

Buol, S.W., F.D. Hole, and R.J. McCracken. 1980. Soll genesis and classification. 2nd ed lowa State Univ. Press, Ames, IA.

Carlson, L., and U. Schwertmann. 1981. Natural ferrihydrites in surface deposits from Fin. land and their association with silica. Geochim Cosmochim. Acta 45:421-429.

Chadwick, O.A., D.M. Hendricks, and W.D. Nettleton. 1987. Silica in duric soils: I, A depositional model. Soil Sci. Soc. Am. J. 51:975-982.

Dijkerman, J.M., M.G. Cline, and G.W. Olson. 1967. Properties and genesis of textural subsoil lamellae. Soil Sci. 104:7-16.

Ernstrom, D.J. 1984. Soil survey of San Luis Obispo County, California, coastal part. USDASCS. U.S. Gov. Print. Office, Washington, DC.

Gee, G.W., and J.W. Bauder. 1986. Particle size analysis. p. 383-411. In A Klute (ed.) Methods of soil analysis. Part 1. 2nd ed. Agron. Monogr. 9. ASA, Madison, WI.

Jackson, M.L., C.H. Lim, and L.W. Zelazny. 1986. Oxides, hydroxides, and aluminosilicates. p. $101-150$. In A. Klute (ed.) Methods of soil analysis. Part 1, 2nd ed. Agron. Monogr. 9. ASA, Madison, WL.

Jenny, H. 1980. The soil resource: Origin and behavior. Ecol. Stud. 37. Springer-Verlag, NY.

Kern, J.P. 1977. Origin and history of upper Pleistocene marine terraces, San Diego, California. Geol. Soc. Am. Bull. 88:1553-1566.

Kodama, $H$. and G.J. Ross. 1991. Tiron dissolution method used to remove and characterize inorganic components in soils. Soil Sci. Soc. Am. J, 55:1180-1187.

MeLean, E.O. 1982, Soil pH and lime requirement, p. 199-224. In A. Klute (ed.) Methods of soil analysis. Part 1. 2nd ed. Agron. Monogr. 9. ASA. Madison, W1.

National Oceanic and Atmospheric Administration. 1983. Climatological data, California. U.S. Dep. of Commerce, National Climatic Center, Asheville, NC.

Orme, A.R., and V.P. Tchakerian. 1986. Quaternary dunes of the Pacific Coast of the Californias. p. 149-175. In W.G. Nickling (ed.) Aeolian geomorphology. Proc. Annu. Binghamton Geomorphol. Symp., 17th, Binghamton. September. Allen and Unwin, Boston.

Ross, C.W., G. Mew, and C.W. Childs. 1989. Deep cementation in late Quaternary sands near Westport, New Zealand. Aust. J. Soil Res. 27:275-288.

Scholie, P.A. 1979. A color llustrated guide to constifuents, textures, cements, and porosities of sandstones and associated rocks. Am. Assoc. of Petroleum Geol. Memoir no. 28. Am. Assoc. Petroleum Geol., Tulsa, OK.

Soil Survey Staff, 1975. Soll Taxonomy: A basic system of soil classification for making and interpreting soil surveys. Agric. Handb. 436. U.S, Gov Print. Office, Washington, DC.

Soil Survey Staff. 1984. Procedures for collecting soil samples and methods of analysis for soil survey. USDA-SCS. Soil Surv. Invest. Rep. no. 1. U.S. Gov. Print. Office, Washington, DC.

Stein, M., G.J. Wasserburg, K.R. Lajoie, and J.H. Chen, 1991, U-series ages of solitary corals from the California coast by mass spectrometry. Geochim Cosmochim. Acta 55:3709-3722.

Torrent, J., W.D. Nettleton, and G. Borst. 1980. Clay illuviation and lamella formation in a Psammentic Haploxeralf in southern California. Soil Sci. Soc. Am. J. 44:363-369.

Veneman, P.L.M., M.J. Vepraskas, and J. Bouma. 1976. The physical significance of soil mottling in a Wisconsin toposequence. Geoderma 15:103-118.

Vepraskas, M.J, and L.P. Wilding. 1983. Albic neoskeletans in agrillic horizons as indices of seasonal saturation and iron reduction. Soil Sci. Soc. Am. J. 47:1202-1208. 